\title{
Properties of Nanoscale Particles on the Basis of Metals Localized Into Biological Tissues
}

\author{
A. P. Shpak, A. B. Brik*, V. L. Karbovskiy, and L. G. Rosenfeld** \\ G. V. Kurdyumov Institute for Metal Physics, N.A.S. of the Ukraine, \\ 36 Academician Vernadsky Blvd., \\ UA-03680 Kyyiv-142, Ukraine \\ "Institute of Geochemistry, Mineralogy and Ore Formation, N.A.S. of the \\ Ukraine, \\ 34 Academician Palladin Blvd. \\ UA-03680 Kyyiv-142, Ukraine \\ "Research Centre of Radiation Medicine, A.M.S. of the Ukraine, \\ 53 Melnikov Str., \\ UA-03050 Kyyiv-50, Ukraine
}

The nanoscale solid-state particles localized into high-mineralised biological tissues (tooth enamel, bone) and into weakly-mineralised tissues (or ganic tissue of mollusc shells, tissue of brain) are considered. The properties of the nanoscale solid-state particles formed on the basis of metallic ions are studied. The data about properties of the nanoscale particles localized into above-mentioned biological tissues are obtained mainly by electron paramagnetic resonance (EPR). For high-mineralised tissues, the problems bound with hierarchy of an internal structure, interaction mechanisms of an organic and mineral substance, an anisotropy of their structure, and impurity crystalline phases are considered. For weakly mineralised tissues, the anomalous resonance signals (caused by the particles with magnetic ordering), which have unique dynamical characteristics, are described. At high level of microwave power, the parabolic zones caused by the coherent phenomena are appeared on the outline of the signals. As concluded, within the brain tissue the physiological (normal) mineralisation and pathological one take place. As suggested, physiological mineral particles play important role in operation of brain and pathological particles and they are the causes of brain diseases. The possible applications of the described results are discussed for solution of fundamental and applied problems bound with nanoscale particles intruded into the biological tissues. The mineral component of high-mineralised tissues and mineral inclusions of weakly-mineralised tissues have the structure of solid-state particles. This fact opens the possibilities for describing the 
processes within the biological tissues by strong physical approaches. Besides, the information about the properties of nanoscale solid-state particles within the biological tissues opens possibilities for creation of the technical systems and equipments, which would use the principles of the biological tissue functioning.

Описано нанорозмірні частинки твердого тіла, що локалізовані у високомінералізованих біологічних тканинах (емаль зубів, кістки) і в слабомінералізованих тканинах (органічна тканина раковин молюсків, тканини мозку). Вивчено властивості цих нанорозмірних частинок, сформованих на основі металічних іонів. Дані про властивості нанорозмірних частинок у вищевказаних біологічних тканинах отримано в основному за допомогою електронного парамагнітного резонансу. Для високомінералізованих тканин розглянуто питання, пов'язані з ієрархією внутрішньої будови, механізмами взаємодії органічної й мінеральної матерії, анізотропією структури і домішковими кристалічними фазами. Для слабомінералізованих тканин описано аномальні резонансні сигнали, обумовлені магнітовпорядкованими частками, що володіють унікальними динамічними характеристиками. При високих рівнях мікрохвильової потужності на контурі цих резонансних сигналів з'являються параболічні зони, обумовлені когерентними ефектами. Зроблено висновки про те, що в тканинах мозку має місце як фізіологічна (нормальна), так і патологічна мінералізація. Припускається, що фізіологічні мінеральні частинки відіграють важливу роль у функціонуванні мозку, а патологічні частки є причиною захворювань мозку. Обговорено можливі застосування описаних результатів для вирішення фундаментальних і прикладних проблем, пов'язаних із нанорозмірними частками в біологічних тканинах. Оскільки мінеральна компонента у високомінералізованих біологічних тканинах і мінеральні включення в слабомінералізованих тканинах мають структуру часток твердого тіла, відкривається можливість для використання строгих фізичних підходів для описання процесів у біологічних тканинах. Крім того, інформація про властивості нанорозмірних частинок твердого тіла, локалізованих у біологічних тканинах, відкриває можливості для створення технічних систем і пристроїв, які б використовували принципи функціонування біологічних тканин.

Описаны наноразмерные частицы твердого тела, локализованные в высокоминерализованных биологических тканях (эмаль зубов, кости) и в слабоминерализованных тканях (органическая ткань раковин моллюсков, ткани мозга). Изучены свойства этих наноразмерных частиц, которые сформированы на основе металлических ионов. Данные о свойствах наноразмерных частиц в вышеперечисленных биологических тканях получены в основном с помощью электронного парамагнитного резонанса. Для высокоминерализованных тканей рассмотрены вопросы, связанные с иерархией внутреннего строения, механизмами взаимодействия органического и минерального вещества, анизотропией структуры и примесными кристаллическими фазами. Для слабоминерализованных тканей описаны аномальные резонансные сигналы, обусловленные магнитоупорядоченными частицами, которые обладают уникальными динамическими ха- 
рактеристиками. При высоких уровнях микроволновой мощности на контуре этих резонансных сигналов появляются параболические зоны, обусловленные когерентными эффектами. Сделаны выводы о том, что в тканях мозга имеет место как физиологическая (нормальная), так и патологическая минерализация. Мы предполагаем, что физиологические минеральные частицы играют важную роль в функционировании мозга, а патологические частицы являются причиной заболеваний мозга. Обсуждены возможные применения описанных результатов для решения фундаментальных и прикладных проблем, связанных с наноразмерными частицами в биологических тканях. Поскольку минеральная компонента в высокоминерализованных биологических тканях и минеральные включения в слабоминерализованных тканях имеют структуру частиц твердого тела, открываются возможности для использования строгих физических подходов для описания процессов в биологических тканях. Кроме того, информация о свойствах наноразмерных частиц твердого тела, локализованных в биологических тканях, открывает возможности для создания технических систем и устройств, которые использовали бы принципы функционирования биологических тканей.

Key words: nanoscale particles, bones, tooth enamel, brain tissue, electron paramagnetic resonance, hydroxylapatite, calcite, ferric oxides.

(Received October 15, 2003)

\section{INTRODUCTION}

The high-mineralised biological tissues can be considered as composite materials, which consist of an organic matrix and nanoscale mineral (inorganic solid state) particles immersed into this matrix [1]. The nanoscale particles are formed on the basis of metallic ions. Most highly mineralised biological tissues are tooth enamel and bones. The mineralisation of enamel and bones makes up 95-97 and $55-75 \%$ of their weight accordingly [2, 3]. Mineralisation of biological tissues is widely spread phenomenon [2-4]. Besides the highmineralised tissues, there are different types of weakly mineralised tissues. Mineral particles (or mineral inclusions) are contained not only in highly mineralised tissues. The small amount of solid-state inclusions contains many biological tissues including brain tissue.

Highly mineralised biological tissues (tooth enamel, bone, mollusc shells, etc.) and mineral inclusions in low mineralised biological tissues are called biominerals [2-4]. More than fifty minerals of different types have been discovered in organisms of humans and animals [2, 4]. The most widely spread biogenic minerals are calcium phosphates, carbonates and oxides, including ferric oxides [2-4]. The X-ray-structural characteristics show that the mineral component of bones and teeth corresponds to the apatite group minerals 
$[2,5,6]$. Therefore, organic matrix of bones and teeth promote to formation the nanoscale particles of apatites. However, organic matrix of mollusc shells promotes to formation the nanoscale particles of calcite or aragonite. The brain tissue promote to formation of nanoscale solid-state magnetic particles on the base of oxides and hydroxides of iron. Inorganic solid-state particles are formed into organic matrix as a result of the biomineralisation processes [2-4]. Physiological (normal) and pathological mineralisation takes place in human organism. Bones and teeth are the result of physiological mineralisation. Different types of stones in kidney are the examples of pathological mineralisation.

The properties of mineral component of biominerals, generated into biological tissues, and properties of appropriate synthetic substances or substances produced by 'nonliving' Nature differ essentially. The mineral substance of biominerals consists of small solidstate particles that have dimensions in nanometer range. The nanoscale particles are immersed into organic matrix, which operate their properties. The surface properties of the mineral particles (the interface between mineral and organic substances) play an important role in formation of the biominerals. As the mineral particles grow on an organic substrate, the structure of the organic substrate (matrix) substantially determines the properties of the mineral particles. The study of mineral particles localized into biological tissues uncovers new possibilities for clarification of co-evolution mechanisms of organic and mineral matter [7], and for solution of different type fundamental problems related to functioning of biological tissues, including brain tissues [8-12].

Study of nanoscale mineral particles of biological tissues serve as well for solution of different type applied problems. The applied problems related to field of ecology, biology, medicine, technology, manufacturing etc [2-4, 8-20]. As well known, demineralisation of bone tissue takes place due to osteoporosis and other diseases of bones $[14,15$, 18-20]. Most fast bone demineralisation takes place under microgravity conditions during space flight $[8,18]$. Information about properties and structure of bone and teeth play important role for treatment of the biological tissues damaged by different diseases [13, 15, 18-20]. The information is important for manufacturing of synthetic materials, which are used as implants in orthopaedics, traumatology, and stomatology $[8,19,20]$. The study of tooth enamel properties is important for retrospective EPR dosimetry of population irradiated due to Chernobyl' accident [16].

Significant efforts were made for investigation of the biominerals and mineral inclusions into biological tissues. The information about properties of the systems contains different references [1-4, 8-20]. Nevertheless, many important issues concerning the struc- 
ture and properties of the nanoscale solid-state particles are still investigated insufficiently.

In a given paper, some general characteristics of biominerals as a special class of substances are described. The properties of the nanoscale solid-state particles formed on the basis of metallic ions and localized into different biological tissues are considered. Main attention of the paper devoted to data obtained by electron paramagnetic resonance. The analysis of new results and results published recently is performed. The new approaches for study of the high-mineralised biological tissues and mineral inclusions into weakly mineralised tissues are described. The possibilities for using of the results for solving different type fundamental and applied problems are discussed as well.

\section{HIERARCHY OF THE INTERNAL CONSTRUCTION OF THE BIOMINERALS}

The biominerals are complex multicomponent systems. The proc-
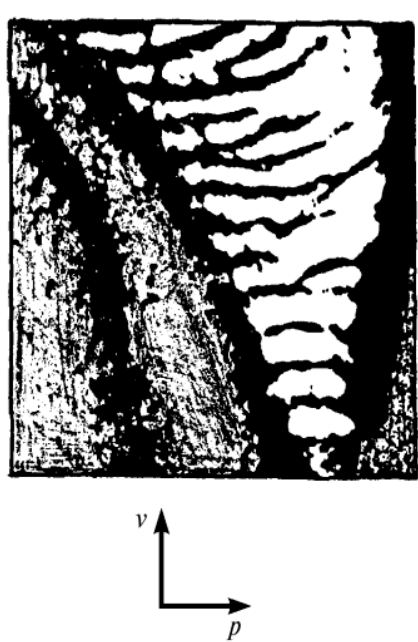

$a$

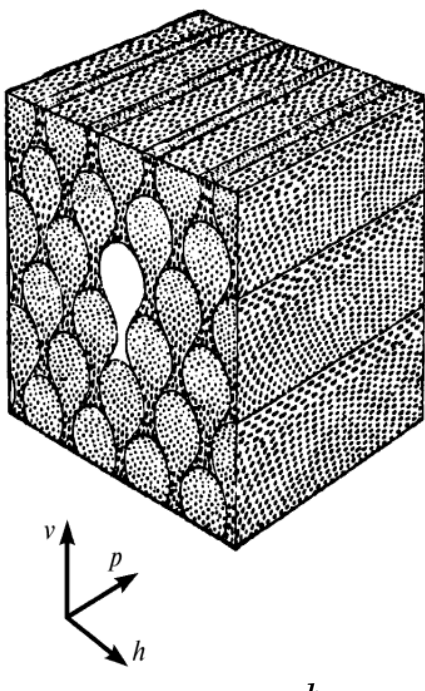

$b$

Fig. 1. Internal structure of tooth enamel. $a-a$ microphotograph of an enamel plate in polarized light (magnification 40). The enamel is located on the right side of the photo. The left side shows the internal part of the tooth. The periodical roughly horizontal strips in the right part correspond to associations of enamel prisms. $b-a$ scheme of an enamel prism structure. Features of a cross section of enamel prisms are illustrated in the plane $(v-h)$. Orientations of nanocrystals making up the prisms are schematically illustrated in planes $(v-p)$ and $(p-h)$. 
esses in the systems can be explained only with account of hierarchy of their internal construction. The hierarchy of internal construction reflects the interrelation and mutual subordination of different subsystems, which form the internal structure of the biominerals.

The enamel of teeth is the most highly mineralised tissue of a human organism. Therefore, it is convenient to explain the fundamental peculiarities of biomineral structure on an example of enamel. There are many data about the structure and properties of tooth enamel [13-15]. Some peculiarities of the internal structure of tooth enamel are illustrated in Fig. 1 and Fig. 2. The native coordinate system is used in Fig. 1. The system has horizontal $(h)$, perpendicular $(p)$, and vertical $(v)$ axes, which correspond to the directions with respect to an in vivo position tooth or bone. Fig. 1 represents the experimental results [16] and a scheme showing the structure of enamel prisms [13]. The Fig. 2 represents the experimental results related to enamel prisms and nanocrystals [14, 15]. The substance of enamel can be divided on organic and mineral components. In the mineral component of tooth enamel, one can identify enamel prism associations (Fig. 1, $a$ ), enamel prisms (Fig. 1, b, Fig. 2, $a$ ), and nanocrystals, which make up these prisms (Fig. $2, b)$. The dimensions of nanocrystals fall into the intervals: length 100-200 $\mathrm{nm}$ and cross dimensions 15-20 nm [2]. The organic component of enamel can be described with two subsystems, conventionally called 'organic-1' and 'organic-2' [12, 16]. The first of
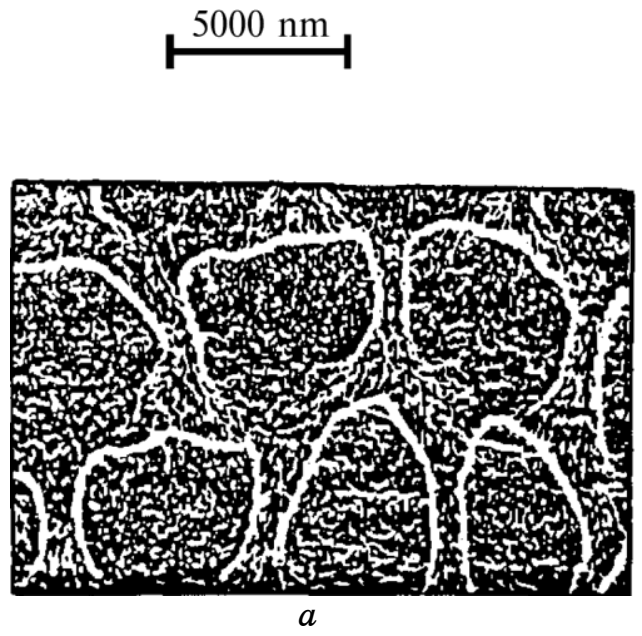
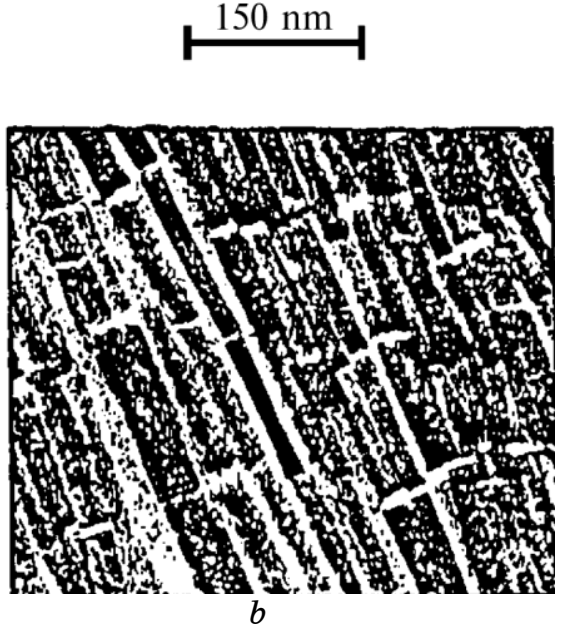

Fig. 2. Electron micro photos of various sections of tooth enamel [14]. Photo $a$ (corresponding to the cross section) shows enamel prisms and photo $b$ (corresponding to the tangential section) shows nanocrystals filling these prisms. 
these subsystems disintegrates under heating in the temperatures range $160-250^{\circ} \mathrm{C}$; the temperature range of disintegration of the second is $300-550^{\circ} \mathrm{C}$. The subsystem 'organic-1' fills the space between enamel prisms; the thickness of the layers is about 10-20 $\mathrm{nm}$. The subsystem 'organic-2' covers nanocrystals; the thickness of its layers is about $2-5 \mathrm{~nm}$.

An important element of the internal construction of enamel is a thin barrier layer covering the nanocrystals $[12,16]$. This layer includes mainly strong bonded and strict oriented in space the water molecules. Molecules $\mathrm{CO}_{2}$, microelements, different type impurity ions, and impurity crystal phases are concentrated inside or close to the barrier layer [17]. The barrier layer control the mass transfer processes into nanocrystals of the biominerals.

The X-ray diffraction spectra of the mineral component of enamel and bones are similar to the spectra of apatite group minerals [2, 5, 6]. Nevertheless, mineral substance of tooth enamel and bones cannot be attributed to any mineral of the apatite group or their mix. Therefore, the most correct name of the mineral particles of the biominerals is bioapatite. However, using usual mineralogical
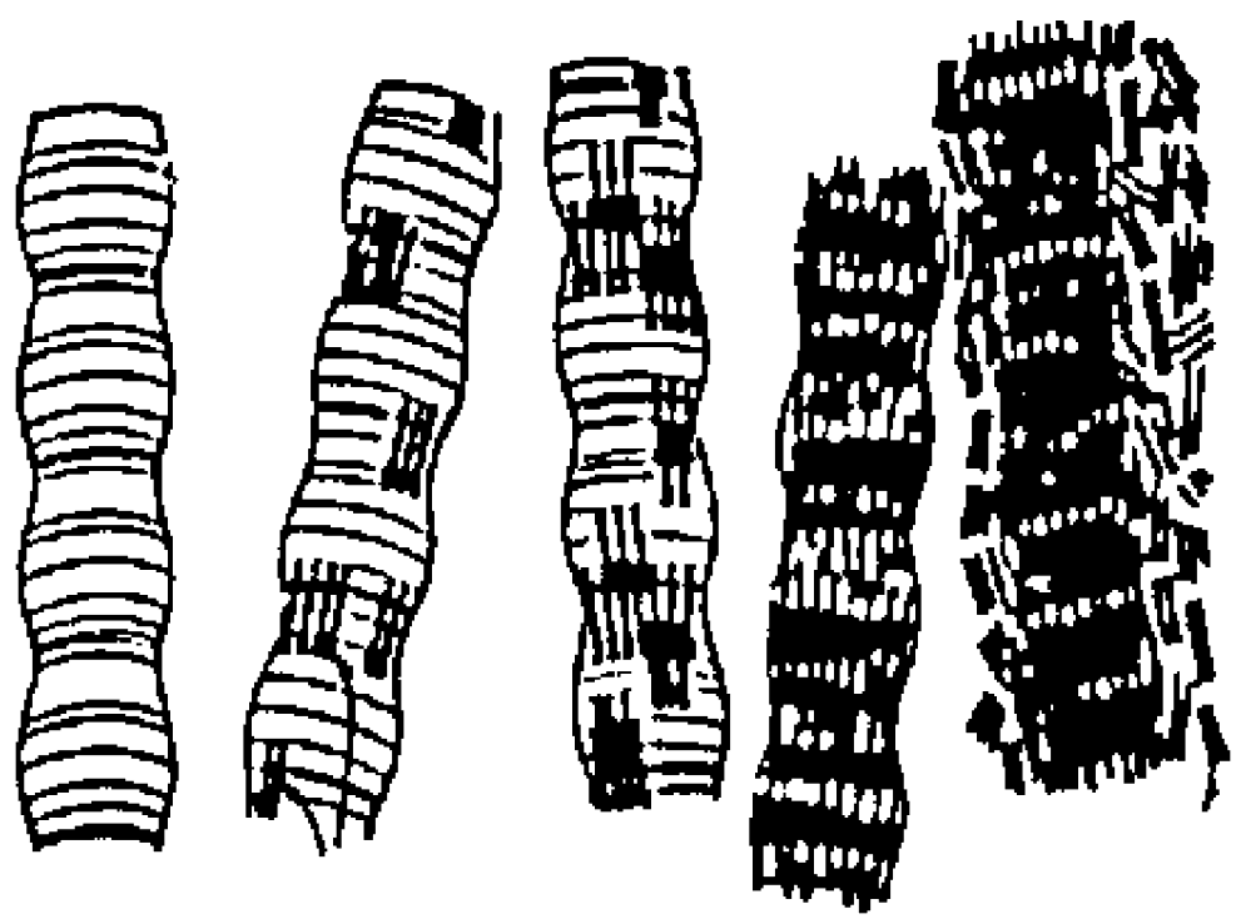

Fig. 3. Scheme of progressive increase in mineralisation of collagen fibrils. The size of the cross section of the fibrils is equal approximately $100 \mathrm{~nm}$. 
terms, it is possible to say that bioapatite is represented mainly by hydroxylapatite $\mathrm{Ca}_{10}\left(\mathrm{PO}_{4}\right)_{6}(\mathrm{OH})_{2}$, oxyapatite $\mathrm{Ca}_{10}\left(\mathrm{PO}_{4}\right)_{6} \mathrm{O}$, dahllite $\mathrm{Ca}_{10}\left(\mathrm{PO}_{4}\right)_{6} \mathrm{CO}_{3}$ and francolite $\mathrm{Ca}_{10}\left(\mathrm{PO}_{4}, \mathrm{CO}_{3}\right)_{6} \mathrm{~F}_{2}$. The mineral component of enamel consists from separate solid-state nanoparticles covered by water-organic layers. Nanocrystals of tooth enamel have different shape and are oriented in the space under the strictly determined law due to anisotropy of organic matrix. Tooth enamel has not cells, nerves, and blood vessels.

The bone tissue has essential distinctions in comparison with enamel because bones have cells, nerves, and blood vessels [15, 1820]. However, intercellular matter of bone tissue has some common features with enamel. Peculiarities of intercellular matter structure of bone tissue are represented in Fig. 3 [14]. A mineral component of a bone (as well as tooth enamel) is represented mainly by bioapatite solid-state nanocrystals (nanoparticles). The nanocrystals make approximately $60 \%$ of bone weight. The weight of an organic component and water is $25-30$ and $10-15 \%$, respectively [2, 3]. The nanocrystals into bone tissue are oriented mainly along a longitudinal axis of collagen fibrils (along vertical axes $v$ ). Dimensions of nanocrystals in bones are about 3-5 times less than those in enamel. According to $[2,17,20]$ bioapatite of a bone can be both in a crystal state and in an amorphous state. The amorphous state of bone mineral particles has to be considered as the X-ray amorphous state. The X-ray amorphous state may be explained both by the absence of a distant order in crystal lattice or by small dimensions of the coherent dispersion areas of the X-ray beams. Mineral component of bones and tooth enamel (besides the bioapatite) includes small amount of treecalciumphosphate, calcite, oxides, and other minerals [17].

Despite distinctions in the internal construction of bones and enamel, some essential peculiarities of their internal construction are similar. The mineral component of these biominerals is represented by small isolated solid-state particles with dimensions in the range of nanometers. The mineral solid-state particles of the tissues are immersed into water organic matrix, which operates their properties. Both tooth enamel and bones have a barrier layer, which control the mass transfer processes into the solid-state particles. The hierarchy of internal construction of the biominerals determines the local and macroscopic properties of the biological tissues.

\section{BIOMINERALS AS MINERAL-ORGANIC NANOASSOCIATED SYSTEMS}

Due to features of internal construction, the biominerals have special properties. According to the results of the papers $[12,16]$, the 
biominerals should be considered as mineral-organic nanoassociated (MONA) systems. The role of structural units in the MONA system play nanocrystals (NCR), organic layers (ORG) and barrier layers (BL), located between the mineral and organic subsystems. All these subsystems NCR, ORG, and BL have sizes in the range of nanometers and are associated to united MONA matter. These subsystems form the elementary cells of MONA matter and have a nonequilibrium electrical charge. The electrical charge of the subsystems can be varied in time due to chance of external conditions [8, $12,16]$. Just electrical charges of the nanoscale subsystems control the mass-transfer processes between an organic and mineral matter of biominerals. The interaction mechanism between nanocrystals and an organic matrix of the MONA systems is associated with the surface energy of the nanocrystals. The organic matrix can effectively operate properties of nanocrystals (and biomineral as a whole) if the full energy of the mineral particles and their surface energy are commensurable.

As known, bones have semi-conductor properties [21]. We believe that just barrier layers control the conductivity of bone tissue and determine the electrical resistance at different polarity of external electric field. It is important to note, that the microelements and impurity ions are located into or close to barrier layers [17]. The ions change the electrical charge of barrier layers that explains the influence of the barrier layer on mass-transfer processes in biominerals $[12,17]$.

Mechanical loading on a bone induces electrical potentials on its surface. Peculiarities of the piezoelectric effect in biological tissues are described in papers $[22,23]$. We believe that small size of subsystems forming internal construction of bones plays essential role in the biological piezoelectric effect. Due to small size, the surface influence essentially on mechanical and electrical state of the nanoparticles. According to reference [12], the nanodimensional piezoelectric effect (NPE) is an important attribute of biological subsystems with dimensions in nanometer range. Due to NPE, a mechanical pressure or stress $\mathbf{P}$ gives rise to an electrical potential gradient in nanoscale subsystems

$$
\nabla \varphi=\left[k^{\text {bio }}\right] \mathbf{P} .
$$

Here $\nabla \varphi$ is a gradient of electrical potential $\left(\nabla=\mathbf{i} \partial / \partial_{x}+\mathbf{j} \partial / \partial_{y}+\right.$ $+\mathbf{k} \partial / \partial_{z}$, the unit vectors $\mathbf{i}, \mathbf{j}, \mathbf{k}$ are directed along three orthogonal axes); $\mathbf{P}-$ mechanical pressure or stress; $\left[k^{\text {bio }}\right]-$ tensor which determined by size, form and properties of a nanoscale subsystem. The NPE is a rather universal phenomenon for nanoscale subsystems [12]. 
The hierarchy of internal structure of biomineral and the special properties of the nanoscale subsystems lead to appearance the special properties of the biominerals as a whole. According to references [24], the different sites of bones have a non-compensated electrical charge. This charge is changed under mechanical stress, external electrical field, and heating [24]. Similar phenomena can be observed for electrets and piezoceramics [25]. Due to NPE, the mechanical stress and the electrical charge of biomineral are interconnected. Mechanical stress of biomineral automatically induces appearance of the electrical charges gradient. Thus, biominerals are electrically-polarized and mechanically-stressed mechanicalelectrical biotextures [12, 16].

The macroscopic state and physiological properties of bone are caused by its electrical polarization and mechanical stress. The study of electrical polarization of bones and development of the methods for influence on the polarization by external factors has a great interest for solution of practical medical problems.

\section{EPR STUDY OF INTERACTION MECHANISMS OF MINERAL AND ORGANIC MATTER}

The study of interaction mechanisms of organic and mineral matter in high-mineralised biological tissues is fundamental problems of biology, medicine, and biomineralogy. The mechanisms determine the processes, which lead to mineralisation and demineralisation of biominerals. Different investigations are devoted to the study of the interaction of organic and mineral substances in mineralised biological tissues [14, 15, 18-20]. However, in spite of large volume of obtained information, this complex and multiplane problem is solved insufficiently. Analysis of literature data show that for progress in the study the new approaches, based on new ideas, is required. It is especially important to develop experimental methods for obtaining information about processes into mineralised tissues, which take place at level of free radicals and nanoscale subsystems $[8,9]$.

Convenient objects for study the interaction mechanisms of organic and mineral matter are the resorbed implants localized into bones of experimental animals. Study of implants, extracted from experimental animals gives possibilities to judge about interaction of lifeless mineral implant matter with organic substances of the live bone tissue. The assimilation processes of implanted materials (hydroxylapatite granules and ceramics blocks) by bones of experimental animals (rats) are described in reference [8].

As known, bone tissue and other biominerals contain so-called native free radicals $R_{n}$, which are formed during the life of biologi- 


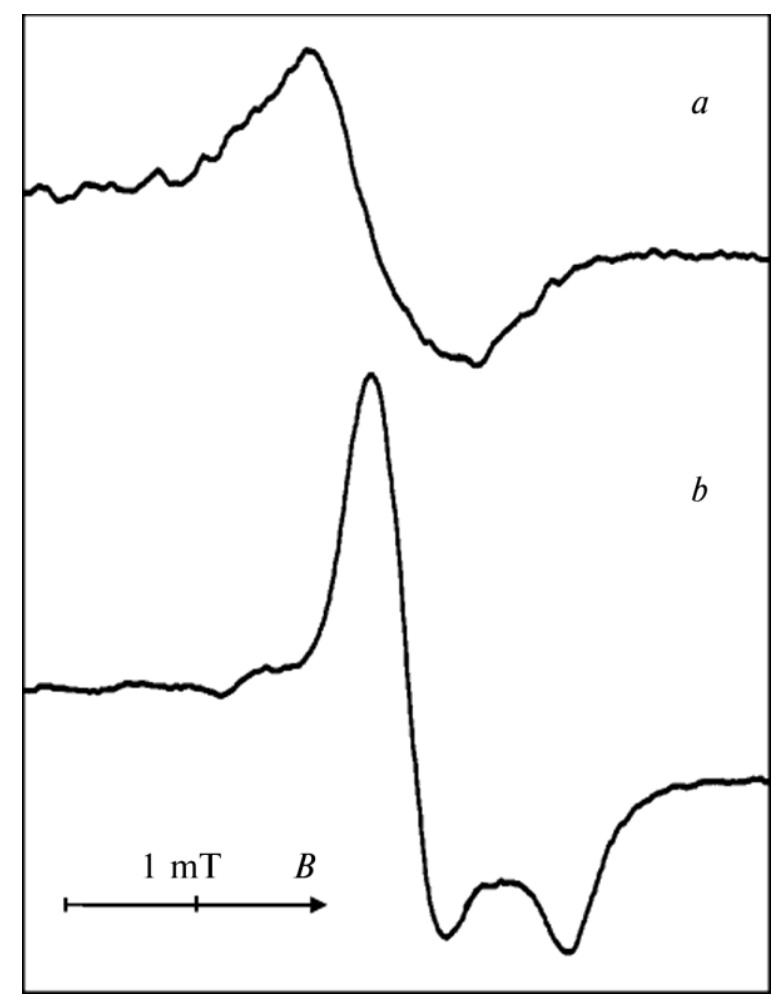

Fig. 4. EPR spectra of implants extracted from bone of experimental animal. The signals $a$ and $b$ are caused by native radicals $R_{n}$ and carbonate radicals $\mathrm{CO}_{2}^{-}$accordingly. The value $B$ shows the scale of magnetic field induction along axis of abscissa.

cal object [8]. The factor of spectroscopic splitting (g-factor) for native radicals is equal about $2.0045 \pm 0.0025$, and width of EPR signal 0.8-1.2 mT. Native radicals are associated with organic substances of the mineralised tissues. The EPR signals of native radicals are absent into initial implant material, because the material does not contain the organic substances. But the implants extracted from bones have the EPR signal of native radicals $R_{n}$ (Fig. 4, a).

Dependences of the intensity of EPR signal $I_{n}$, which is caused by radicals $R_{n}$, versus duration of stay of the resorbed implant in an organism of the animal are represented in Fig. 5. If the time interval $t$ is equal approximately (15-20) days, the intensity of the signal $I_{n}$, is maximum. The quantity of radicals $R_{n}$ in implanted material decreases at further increase the time interval $t$. Intensity of native radical EPR signal of bone tissue is equal approximately 0.3 units, thus intensity of EPR signals $I_{n}$ of extracted implants much more then intensity of the signal in bone tissue (Fig. 5). However, 


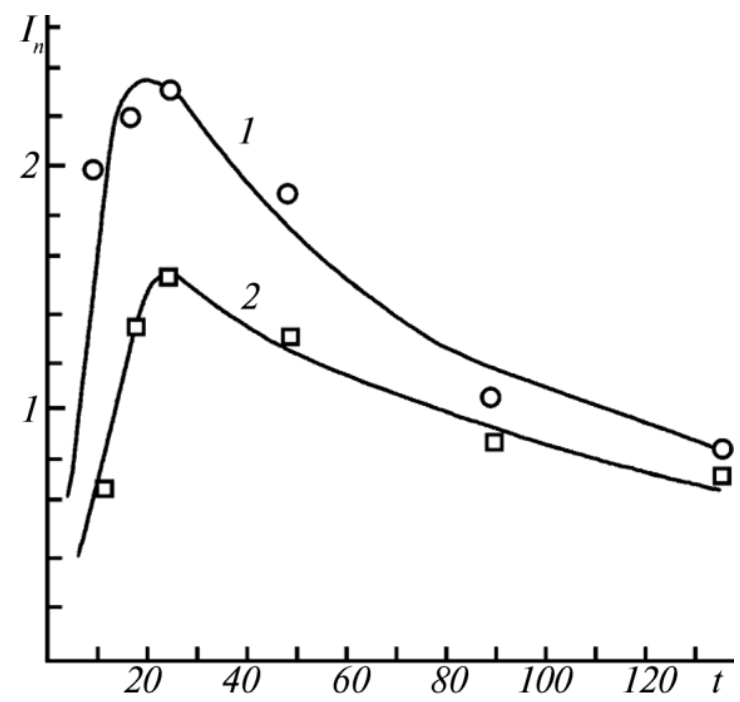

Fig. 5. Dependences $I_{n}$ (measured in arbitrary units) versus time interval $t$ (measured in days). The curves 1 and 2 correspond to granules and ceramic blocks.

the quantity of organic substance in implants is less, than in bone tissue. Thus, the concentrations of native radicals in organic substance, penetrated into implant material, much more then concentration of native radicals in organic matrix of bone tissue. According to Fig. 5, the intensity of EPR signals of the native radicals depends as well from the characteristics of the implanted material.

After irradiation by gamma rays, the bones and other biominerals have EPR signals caused by $\mathrm{CO}_{2}^{-}$radicals. The presenters of the radicals are carboxyl groups of amino acids, associated with mineral particles of mineralised tissues, and $\mathrm{CO}_{2}$ molecules, located on surfaces of the bioapatite nanocrystals [8]. Irradiation of initial implants materials does not lead to formation of $\mathrm{CO}_{2}^{-}$radicals due to absence of the presenters of the radicals. But all implants extracted from bones and irradiated by gamma rays have EPR signals caused by radicals $\mathrm{CO}_{2}^{-}$(Fig. 4). Thus, the stay of implants into bones of live animals produces the presenters of $\mathrm{CO}_{2}^{-}$radicals into the implanted materials. The intensity of EPR signals $I_{c a r b}$, which are caused by $\mathrm{CO}_{2}^{-}$radicals, increase versus the duration of stay of the implants into bones (Fig. 6). The dependences of $I_{\text {carb }}$ versus the time interval $t$ are non-linear. The intensities of signals $I_{\text {carb }}$ for different implanted materials are different. Dependences, represented in Fig. 6, show, that intensity of EPR signals $I_{\text {carb }}$ continue to grow with increase the time interval $t$. The EPR signals of $\mathrm{CO}_{2}^{-}$radicals in intact bone tissue are about three times more intensive, than 


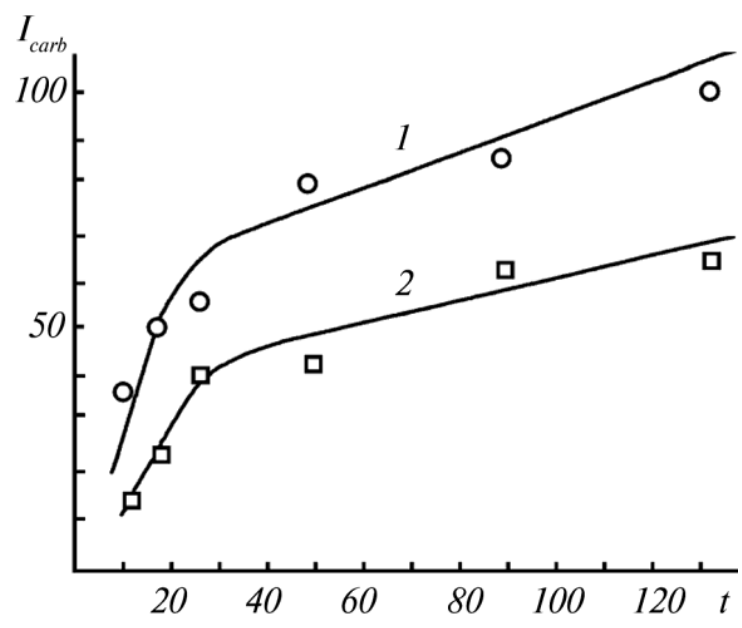

Fig. 6. Dependences $I_{\text {carb }}$ (measured in arbitrary units) versus time interval $t$ (measured in days). The curves 1 and 2 correspond to granules and ceramic blocks.

maximal EPR signals in implanted materials. The spectroscopic characteristics of $\mathrm{CO}_{2}^{-}$radicals in implant materials are similar to the appropriate characteristics of $\mathrm{CO}_{2}^{-}$radicals in bone tissue. The perpendicular and parallel components $g$-tensor of $\mathrm{CO}_{2}^{-}$radicals are equal $g_{\perp} \approx 2.0020 \pm 0.0005, g_{\|} \approx 1.9970 \pm 0.0005$.

So, except the native radicals $R_{n}$, the assimilation processes of the implants by bone tissue can be studied as well with the help of carbonate radicals $\mathrm{CO}_{2}^{-}$. Formation of native radicals $R_{n}$ and presenters of carbonate radicals $\mathrm{CO}_{2}^{-}$reflects different biostimulated processes into implant material. The native radicals $R_{n}$ and the carbonate radicals $\mathrm{CO}_{2}^{-}$have a different nature and they are located in different subsystems of a bone tissue, therefore with the help of these two radicals the assimilation processes of implants by bone tissue can be studied independently.

Interaction of organic (mainly collagen) molecules and surface of hydroxylapatite have following peculiarities. As the collagen molecules have large electrical dipole moment, they create around of themselves a strong electrical field. The electrical field of collagen influences on hydroxylapatite and can promote to moving of electrons between the molecules and hydroxylapatite. Because of this physical-chemical interaction, the formation of presenters of $\mathrm{CO}_{2}^{-}$ radicals on the pole of the electrical dipole takes place. We think that collagen molecules are connected with hydroxylapatite by carboxyl group $(\mathrm{COOH})$ of the protein. Irradiation of the associated mineral-organic matter leads to formation of stable $\mathrm{CO}_{2}^{-}$radicals.

EPR method gives information about processes in bone tissue at 
level of free radicals and nanoscale subsystems. Because the subsystems are relatively simple, the processes into mineralised biological tissues (at level of nanoscale subsystems) can be described with the help of relatively simple physical-chemical models. Within the framework of the models, the influence of biologically active substances, cells, and other biological subsystems can be expressed by external conditions of the nanoscale particles. These external conditions can be described in the terms, which are convenient for physical models (electrical potentials, values of potential barriers, concentration and mobility of impurity ions, $\mathrm{pH}$ local value, etc.)

So EPR investigations of native radicals $R_{n}$ and carbonate radicals $\mathrm{CO}_{2}^{-}$open unique possibilities for study interaction mechanisms of organic and mineral matter and for examination of assimilation processes of resorbed implants by bone tissue. We hope that the EPR investigation will serve for improving of synthetic materials, which are used for treatment of bone diseases.

\section{ANISOTROPY OF TOOTH ENAMEL AND BONES}

Tooth enamel and bones are highly textured systems. Accordingly, EPR signals of enamel and bones display anisotropy when the plates manufactured from the biominerals are rotated in magnetic field $[16,26,27]$. The EPR signal anisotropy in biominerals is caused by anisotropy of the organic matrix and phenomenon of bioepitaxy. Due to bioepitaxy the organic matrix of the biominerals influence on orientation of the nanocrystals. Diseases of teeth and bones change properties of biominerals and change the anisotropy effects. EPR investigations open possibilities for study the changes caused by diseases of bones and teeth.

The EPR signal of tooth enamel, registered in the region of the spectroscopic splitting factor $g \approx 2.0$, represents a superposition of signals caused by different carbonate groups. According to [28] the contribution of different carbonate groups to the total EPR signal

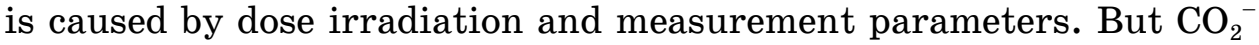
radicals give main contribution to the EPR signal close to $g \approx 2.0$. In unheated enamel, the $\mathrm{CO}_{2}^{-}$radicals can be described by the axial and orthorhombic centres [29,30]. The orthorhombic centres have $\mathrm{g}$ tensor with principal values $g_{1} \approx 2.0030, g_{2} \approx 2.0015, g_{3} \approx 1.9973$ and axial centres $g$-tensor with the principal values $g_{\perp} \approx 2.0023$ and $g_{\|}=1.9973$ [29]. The temperature stability of orthorhombic centres is less then axial centres. Due to the heating of enamel, the transformation of orthorhombic centres to axial ones take place. The alignment of $\mathrm{CO}_{2}^{-}$radicals caused by the transformation is described in papers [16, 26].

Fig. 7 and Fig. 8 show the EPR signals of enamel plate and 
changes of the signals due to heating and rotation of the samples. The figures have shown that the form of the signals change due to rotation of the enamel plate in the magnetic field and due to heating of the sample. $\mathrm{CO}_{2}^{-}$radicals of different type produce the EPR signals represented in the figures. The extrema of the curves located in magnetic fields $B_{1}$ and $B_{2}$ (see dashed arrows) correspond to $g_{1} \cong 2.003$ and $g_{2} \cong 1.997$. The intensities of the peaks are marked as $I_{\perp}$ and $I_{\|}$. We will characterize the variations of the EPR signals intensity due to rotation of enamel plate around the axes $h, p, v$ by changes of peaks $I_{\perp}$ and $I_{\|}$. The experimental results for the initial and heated samples are shown in Fig. 9. In this figure, the rotation axes are shown in the circles at the top of the drawing. The experimental results can be described with account of the transformation of orthorhombic centres to axial due to heating of the samples. The transformation leads to alignment of $\mathrm{CO}_{2}^{-}$radicals and accordingly to increasing of some EPR peaks due to heating of the enamel plate $[16,26]$.

Orientation of $\mathrm{CO}_{2}^{-}$radicals in space can be determined by oxygen-

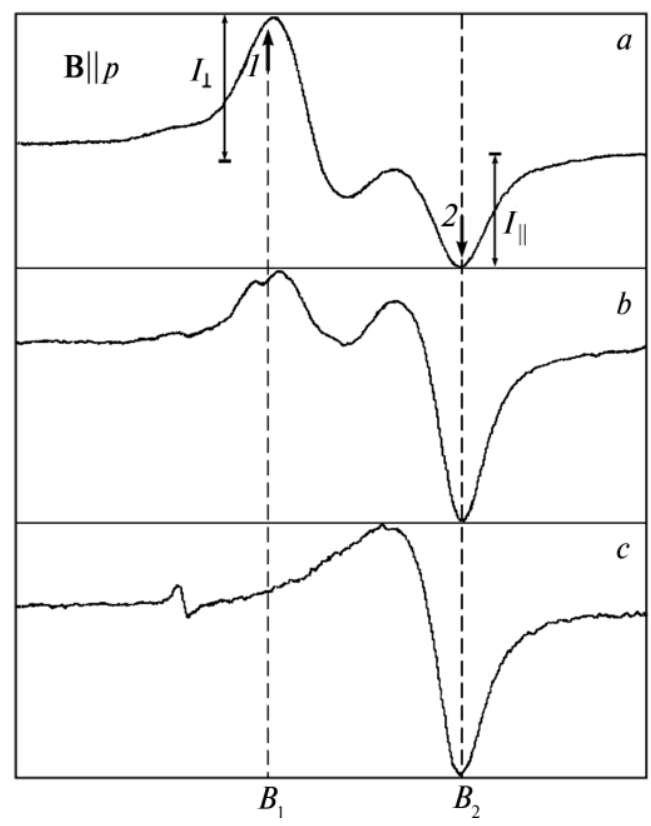

Fig. 7. EPR signals in an enamel plate at $\mathbf{B} \| p$. The spectra $a, b, c$ corresponds to plates heated one hour at temperatures of 75,168 and $285^{\circ} \mathrm{C}$ respectively. Microwave power $P_{0}$ is equal approximately $80 \mathrm{~mW}$, modulation amplitude $0.025 \mathrm{mT}$, modulation frequency $100 \mathrm{kHz}$. The vertical dashed lines indicate the fields $B_{1}$ and $B_{2}$ at which the peaks $I_{\perp}$ and $I_{\|}$are registered. 
oxygen direction of the radicals. Two groups of carbonate radicals in tooth enamel-chaotic and ordered (oriented) - have been described in different papers $[16,26,27]$. The chaotic centres produce the orthorhombic EPR signal and oriented centres produce the axial EPR signal. The quantity of chaotic and oriented centres we will designate as $N_{1}$ and $N_{2}$ accordingly. The distribution of $N_{1}$ and $N_{2}$ centre orientation are described by distribution functions $f_{1}\left(\varphi_{\mathrm{i}}, \theta_{\mathrm{i}}\right)$ and $f_{2}\left(\varphi_{\mathrm{i}}, \theta_{\mathrm{i}}\right)$, where $\varphi_{\mathrm{i}}$, and $\theta_{\mathrm{i}}$ are the azimuth and polar angle of the direction oxygen-oxygen for $\mathrm{CO}_{2}^{-}$radicals in the native coordinate system $h, p, v$. In Refs. [16, $26]$, the supposition was made that $N_{1}$ centres are randomly oriented in the enamel plate and accordingly the associated EPR signal is similar to that of powdered samples. Nevertheless, $N_{2}$ centres have fixed orientation. Accordingly, their EPR signals depend on orientation of the plate in the magnetic field $\mathbf{B}$. So, for plate of enamel the form and position of EPR signals are determined by function $f_{2}\left(\varphi_{\mathrm{i}}, \theta_{\mathrm{i}}\right)$ and ratio $N_{1} / N_{2}$.

The experimental results shown in Fig. 9 can be described by supposition that distribution of $N_{2}$ radical orientations in the planes $(v-p)$ and $(h-p)$ can be described by the following expressions [16, 26]:

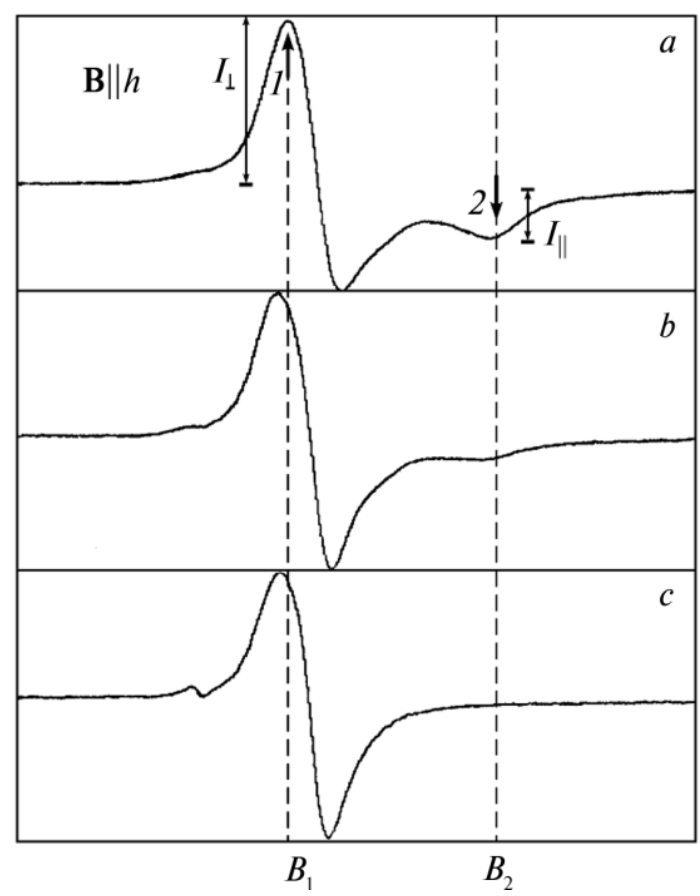

Fig. 8. EPR signals in an enamel plate at $\mathbf{B} \| h$. For spectra $a, b, c$, the heating and modes of spectra registration are described in Fig. 7. 


$$
\begin{aligned}
& N_{2, v p}\left(\theta_{\mathrm{i}}\right) \approx N_{2, v p, \max } \exp \left\{-\left[\left(\theta_{\mathrm{i}}-70^{\circ}\right) / 40^{\circ}\right]^{2}\right\}, \\
& N_{2, h p}\left(\varphi_{\mathrm{i}}\right) \approx N_{2, h, \text { max }} \exp \left\{-\left[\left(\varphi_{\mathrm{i}}-90^{\circ}\right) / 25^{\circ}\right]^{2}\right\} .
\end{aligned}
$$

Values $N_{2, v p \text {,max }}$ and $N_{2, h p \text {, max }}$ are the maximal quantities of $\mathrm{CO}_{2}^{-}$radicals, which are oriented in the planes $(v-p)$ and $(h-p)$ respectively. Results of calculations by equations (1) and (2) are shown in Fig. 9 by dashed lines. When a heated plate is rotated around axis $p$, the intensity $I_{\|}$is almost zero. Thus, the quantity of $\mathrm{CO}_{2}^{-}$radicals whose $g_{\|}$direction lay in the plane $(h-v)$ is very small. Experimental data show that

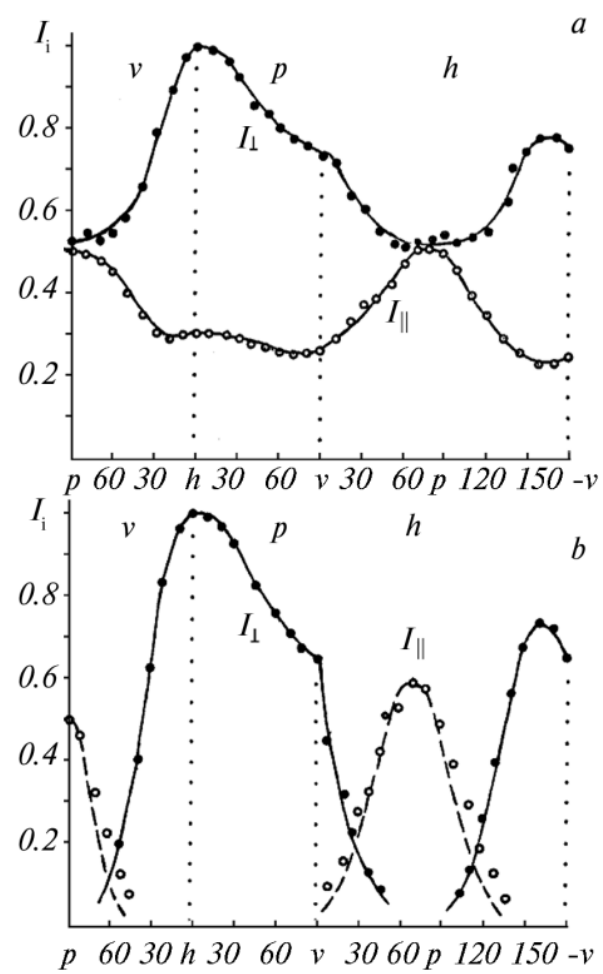

Fig. 9. Dependence of peak intensities $I_{\mathrm{i}}(\mathrm{i}=\|, \perp)$ versus orientation of enamel plate in the magnetic field. Intensities of peaks, $I_{\perp}$ and $I_{\|}$, are normalized to the maximum of peak intensity $I_{\perp}$ (the intensity at $\mathbf{B} \| h$ ). The vertical dotted lines divide the dependencies for different rotation axes. The rotation axes are specified in the top of the drawings. The angles, which describe the orientation of the vector $\mathbf{B}$, are plotted on the abscissa. When the vector $\mathbf{B}$ is parallel to any of axes $v, p, h$, a symbol of the appropriate axis is specified on the abscissa. $a$-an enamel plate heated at $75^{\circ} \mathrm{C}$. $b$-an enamel plate heated at $285^{\circ} \mathrm{C}$. The dashed lines correspond to the calculated dependencies. 


$$
N_{2, h p, \max } \approx 0.85 N_{2, v p, \max }>>N_{2, h v, \text { max. }}
$$

Equations (1)-(3) describe approximately the anisotropy effects in incisors that are not damaged by caries. However, anisotropy of EPR signals is different for diseased and healthy enamel. For diseased teeth, the anisotropy is smaller. Therefore, the anisotropy effects can be used for study the enamel structure and its changes due to decease. We believe that peculiarities of the EPR signal anisotropy for tooth enamel are caused by genetic factors (like finger prints). The parameters of functions (1)-(3) for teeth with different susceptibility to illnesses should be different. Experimental studies of anisotropy effects for enamel of milk teeth (after their natural fallout) would be a great interest. We believe that measurement the anisotropy of milk teeth will open the possibilities for estimation of caries risk for permanent teeth in the future. The information about the risk of the future disease will enable to take the appropriate preventive actions for the person.

The anisotropy of the EPR signal of $\mathrm{CO}_{2}^{-}$radicals in bones substantially differs from the anisotropy in enamel. Variations of EPR signal shape due to rotation of a bone plate in the magnetic field

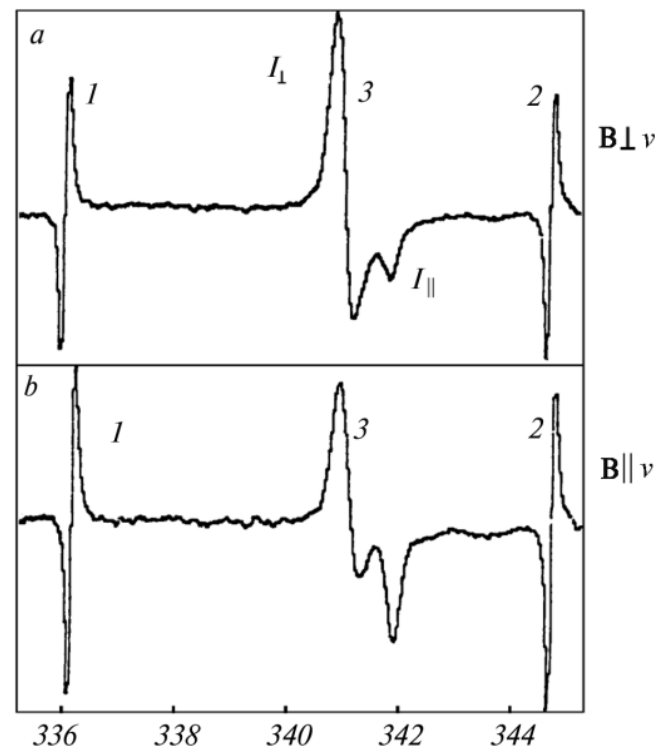

Fig. 10. The EPR spectra of rat bone plate at different orientation in magnetic field. Spectra $a$ and $b$ correspond to $\mathbf{B} \perp v$ and $\mathbf{B} \| v$ accordingly where $\mathrm{v}$ is vertical axes of native coordinate system. Numbers 1 and 2 show the signals of standard sample $\left(\mathrm{MgO}: \mathrm{Mn}^{2+}\right)$. Number 3 indicates the EPR signals of $\mathrm{CO}_{2}^{-}$radicals. The abscissa shows value of magnetic field induction (mT). 
are similar to the variations of enamel. But orientations providing the approximately same signal shape are different for bones and enamel because the functions describing the spatial orientation of $\mathrm{CO}_{2}^{-}$radicals are different for enamel and bones (Fig. 10). The direction oxygen-oxygen axis of $\mathrm{CO}_{2}^{-}$radicals in the bones is primarily parallel to the directed along axis $v$ of the native coordinate system of bone.

The anisotropy of EPR signals for enamel and bones can be described by texture coefficients $k_{1}=I_{\perp, h} / I_{\|, h}$ and $k_{2}=I_{\perp, p} / I_{\|, p}$. In these formulas the values $I_{\perp, h}$ and $I_{\|, h}$ correspond to the plates with orientations $\mathbf{B}_{0} \| h$, while the values $I_{\perp, p}$ and $I_{\|, p}$ correspond to the plates with orientations $\mathbf{B}_{0} \| p$. The texture coefficients have been changed due to illness of enamel by caries and due to illness of bones by osteoporosis [31]. The coefficients change as well for rat bones after imitation of space flight conditions [32]. The texture coefficients open new possibilities for study of anisotropy and other properties of the high-mineralised biological tissues.

\section{EPR OF THE IMPURITY CRYSTAL PHASES IN BIOMINERALS}

The information about phase composition of mineral component of biominerals and their synthetic analogues has great importance for solution different fundamental and applied problems. The phase composition of biominerals varies with age of biological objects and due to diseases of bones and teeth. A special interest to phase composition of biominerals is connected with study of osteoporosis and bone demineralisation during space flight [9] and with application of synthetic hydroxylapatite and tricalciumphosphate for treatment of bone diseases [8].

Numerous references [2-4, 13-20] deal with the study of structure and phase composition of the mineral component of bones and teeth by means of different methods. Most unequivocally the phase composition of mineral component of biominerals can be determined the by means of the X-ray phase analysis method. However, possibilities of the X-ray phase analysis method and other traditional methods for study the mineral phases of biominerals are limited. It is caused by many factors and, in particular, by the fact that the sensitivity of these methods is relatively low. Small sizes of particles, which form the mineral component of biominerals, and defectiveness of structure of these particles complicates research of biominerals by the X-ray phase analysis method. Special difficulties arise during study of impurity mineral-crystal phases in biominerals. As impurity-crystal phases, we understand the crystal phases, which are presented in biominerals and synthetic materials in very small amounts. It is important to note that, despite the small 
amount, namely the impurity crystal phases determine the mineralisation and demineralisation processes of bones and teeth (like impurity ions determine the semiconductors properties).

Until recently, the electron paramagnetic resonance has not been used for determination of phase composition of biominerals and their synthetic analogues. Application of EPR for study of impurity crystal phases is based on the following factors [17]. Firstly, this method has high sensitivity, and, secondly, the EPR characteristics of paramagnetic ions (including $\mathrm{Mn}^{2+}$ and $\mathrm{Cr}^{3+}$ ), located in different crystal lattices, are essentially different. It give possibilities to investigate the composition of impurity crystal phases by EPR of $\mathrm{Mn}^{2+}$ and $\mathrm{Cr}^{3+}$ ions and to study the defectiveness of the phases located in biominerals and their synthetic analogues.

The ground state of ions $\mathrm{Mn}^{2+}$ corresponds to orbital singlet, i.e. the orbital moment of this ion is equal to zero. This fact promotes to registration of EPR signals of powder samples for different crystal lattices, including the crystal lattices with low symmetry and high defectiveness. For ions $\mathrm{Cr}^{3+}$, another situation takes place. For powdered samples, the EPR signals of ions $\mathrm{Cr}^{3+}$ are successfully registered only in crystals with high symmetry and small defectiveness. Just these impurity crystals phases frequently form due to heating of biominerals and their synthetic analogues.

Wide abundance of manganese as an impurity into biominerals and listed above peculiarities of ions $\mathrm{Mn}^{2+}$ make the EPR of ions $\mathrm{Mn}^{2+}$ a rather universal method for the phase analysis of biominerals and their synthetic analogues. The marked above peculiarities of ions $\mathrm{Cr}^{3+}$ allow the expanding of EPR possibilities for study of impurity crystal phases.

As known, the structure of apatite has two positions of calcium ions $\mathrm{Ca}(\mathrm{I})$ and $\mathrm{Ca}(\mathrm{II})$ [5, 17]. The positions $\mathrm{Ca}(\mathrm{I})$ and $\mathrm{Ca}(\mathrm{II})$ correspond to coordination complexes $\mathrm{CaO}_{9}$ and $\mathrm{CaO}_{6} \mathrm{OH}$. The quantity of calcium ions in positions $\mathrm{Ca}(\mathrm{I})$ and $\mathrm{Ca}(\mathrm{II})$ correspond to 40 and $60 \%$, accordingly. Ions $\mathrm{Mn}^{2+}$, which replace ions $\mathrm{Ca}^{2+}$ in positions $\mathrm{Ca}$ (I) and $\mathrm{Ca}(\mathrm{II})$, will be marked as $\mathrm{Mn}(\mathrm{I})$ and $\mathrm{Mn}(\mathrm{II})$ [17]. The detailed information about spin Hamiltonian parameters of ions $\mathrm{Mn}^{2+}$ in positions $\mathrm{Ca}(\mathrm{I})$ and $\mathrm{Ca}(\mathrm{II})$ can be found in references [33, 34]. The EPR signals, caused by the ions $\mathrm{Mn}(\mathrm{I})$ and $\mathrm{Mn}(\mathrm{II})$ in apatite structure, are registered separately (Fig. 11).

Electron configuration of $\mathrm{Mn}^{2+}$ ions corresponds to $3 d^{5}$, electron spin is equal to $5 / 2[33,34]$. The spectra in Fig. 11 correspond to electron transition $+1 / 2 \leftrightarrow-1 / 2$. The six lines in the spectrum are caused by hyperfine interaction of the electron with the nucleus ${ }^{55} \mathrm{Mn}$. The positions of the EPR lines of ions $\mathrm{Mn}^{2+}$ is determined by symmetry of crystal lattice and by other peculiarities of near surrounding of this ion. Due to quadruple moment of the manganese 
nucleus, the EPR spectra of ions $\mathrm{Mn}^{2+}$, besides the basic six lines, as a rule, have an additional structure caused by forbidden transitions.

In the biogenic apatite, the EPR signals caused by ions $\mathrm{Mn}^{2+}$ are absent. This experimental result is surprising, as the mineral phases of bones and teeth are presented mainly by apatite, and, besides, these biominerals contain a lot of manganese. The absence of the EPR signals of ions $\mathrm{Mn}^{2+}$ in the biogenic apatite requires further experimental research. However, this fact allows the study of regeneration processes of bone tissue by using of implants with manganese impurity. If during regeneration of bone tissue the complete dissolution of implant material takes place, the manganese ions in the regenerated bone will be absent. However, if assimilation of large fragments of implant material takes place, the regenerated bone will contain the ions $\mathrm{Mn}^{2+}$ in the apatite structure of regenerated bones. Thus, EPR research of manganese ion dynamics in implant material and in regenerated bone tissue give possibilities

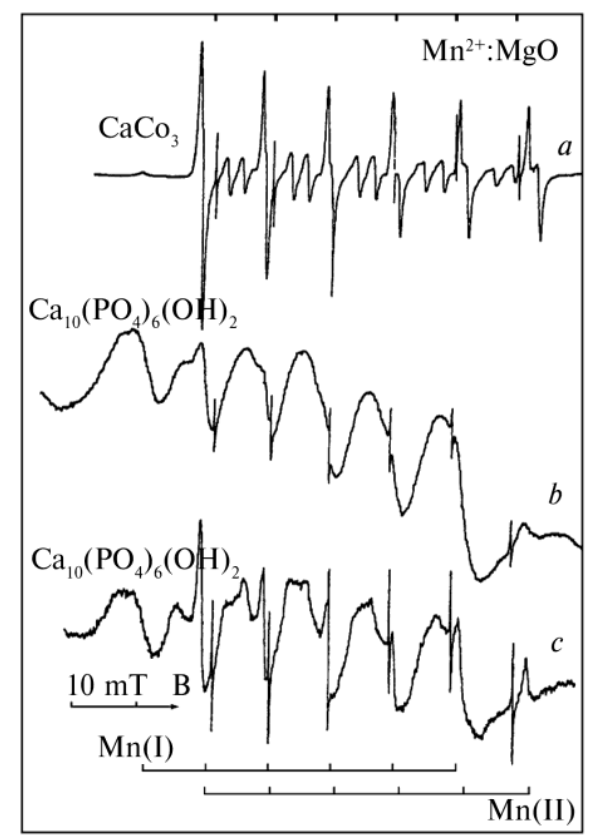

Fig. 11. The EPR spectra illustrating the dynamics of ions $\mathrm{Mn}^{2+}$ in different samples. The spectrum $a$ corresponds to calcite with large concentration $(0 . n \%)$ of manganese ions. The spectra $b$ and $c$ correspond to the samples of synthetic hydroxylapatite, heated at temperatures 900 and $1000^{\circ} \mathrm{C}$, accordingly. On all spectra, there are narrow signals from a reference sample $\left(\mathrm{MgO}: \mathrm{Mn}^{2+}\right)$. The position of these lines is designated above the drawing. Below the drawing, the lines of ions Mn(I) and Mn(II), located in different calcium positions of hydroxylapatite, are designated. 
for obtaining the unique information about assimilation processes of implant materials by living biological tissue.

The EPR spectra of $\mathrm{Mn}^{2+}$ in calcite (Fig. 11) have the basic six doublet lines and additional weak doublet signals between these lines. The weak doublet signals are caused by forbidden transitions. The parameters of spin Hamiltonian of ions $\mathrm{Mn}^{2+}$ in calcite are described in reference [34]. Width of the EPR signals of ions $\mathrm{Mn}^{2+}$ in calcite much depends on the concentration of these ions. Using the width of EPR signals, it is possible to estimate the local concentration of $\mathrm{Mn}^{2+}$, and the degree of defectiveness of calcite structure.

The EPR spectra of ions $\mathrm{Mn}^{2+}$ in $\mathrm{CaO}$ and $\mathrm{MgO}$ represent the six narrow lines [17]. The intensity of forbidden transitions for these crystals is small. The simplicity of the EPR spectra in $\mathrm{CaO}$ and $\mathrm{MgO}$ is caused by high symmetry of their crystal lattice. The parameters of the EPR spectra of ions $\mathrm{Mn}^{2+}$ in $\mathrm{CaO}$ and $\mathrm{MgO}$ are close, but not identical [17]. The most essential distinctions take place for highfield spectrum lines. The Fig. 12 illustrates the EPR signals of $\mathrm{Mn}^{2+}$ in impurity crystal phases $\mathrm{CaCO}_{3}$ and $\mathrm{CaO}$, which are localized into human bone tissue. The signals in impurity crystal phases $\mathrm{CaCO}_{3}$ and $\mathrm{CaO}$ we will design as $I_{1}(\mathrm{Mn})$ and $I_{2}(\mathrm{Mn})$ accordingly.

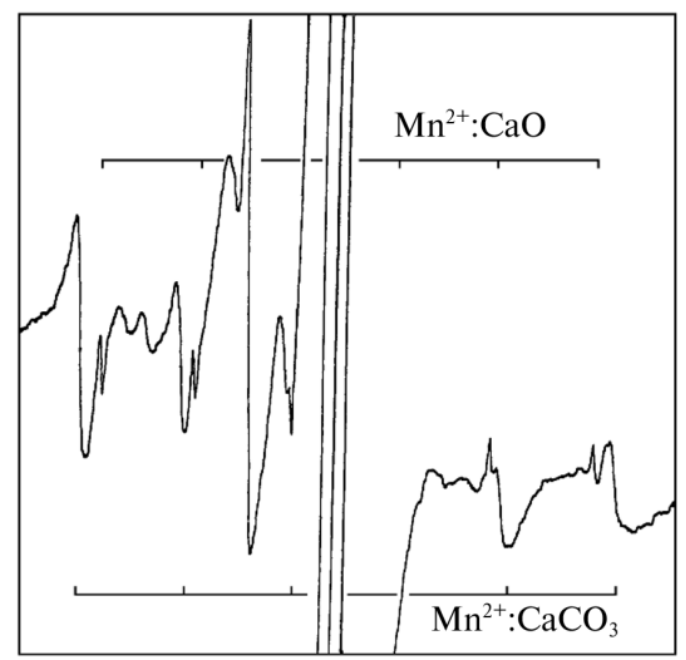

Fig. 12. The EPR spectrum of human femur bone. The sample was heated at $T=900^{\circ} \mathrm{C}$ and irradiated by $\gamma$-rays (isotope ${ }^{60} \mathrm{Co}$ ). In addition to lines, caused by the ions $\mathrm{Mn}^{2}$ in impurity crystal phases of $\mathrm{CaO}$ and $\mathrm{CaCO}_{3}$, it is possible to see the other EPR signals. The signals between the 2nd and 3rd lines of manganese are caused by ions $\mathrm{O}^{-}$, located in positions of hydroxyl groups of the apatite structure. Different paramagnetic centres, including $\mathrm{CO}_{2}^{-}$- radicals, located on surfaces of bioapatite nanocrystals, cause the signals between the $3 \mathrm{rd}$ and 4 th lines of manganese. 


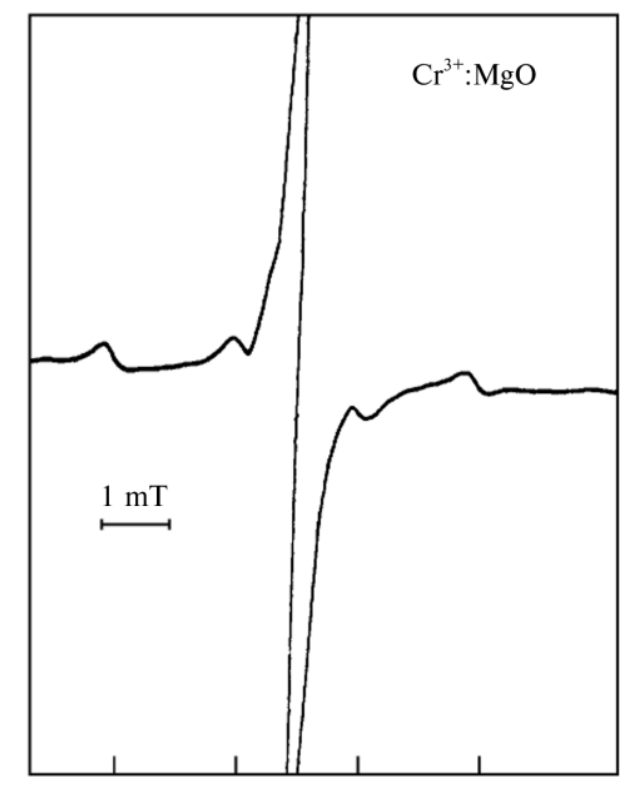

Fig. 13. The EPR spectrum of ions $\mathrm{Cr}^{3+}$ localized in impurity crystal phase $\mathrm{MgO}$ of rat bone. The bone was heated at $T=900^{\circ} \mathrm{C}$. Chromium isotopes with nonmagnetic nuclei cause the central line. Four weak lines are caused by isotope ${ }^{53} \mathrm{Cr}$ (nuclear spin $3 / 2$, abundance-9.5\%). The lines of an isotope ${ }^{53} \mathrm{Cr}$ are designated by small lines down of the drawing.

As known, electron configuration of ion $\mathrm{Cr}^{3+}$ corresponds to $3 d^{3}$ and electron spin is equal to $3 / 2$, [34]. The chromium isotopes ${ }^{50} \mathrm{Cr}$, ${ }^{52} \mathrm{Cr}$, ${ }^{54} \mathrm{Cr}$ do not have magnetic nuclei. However, the isotope ${ }^{53} \mathrm{Cr}$ has a magnetic nucleus with spin $3 / 2$. Abundance of the isotope ${ }^{53} \mathrm{Cr}$ is equal to $9.5 \%$. The EPR spectra of ions $\mathrm{Cr}^{3+}$ in rat bone are represented in Fig. 13. The experiment shows that the bone includes the impurity crystal phase of $\mathrm{MgO}$. The central line in the spectrum corresponds to chromium isotopes with nonmagnetic nucleuses and to electron transition $+1 / 2 \leftrightarrow-1 / 2$. Besides, the EPR spectrum contains four weak signals. These four EPR signals are caused by hyperfine interaction of the electron with the nucleus ${ }^{53} \mathrm{Cr}$. The hyperfine interaction constant and g-factor of ions $\mathrm{Cr}^{3+}$ in the crystal phase $\mathrm{MgO}$ is equal to $A=1.78 \pm 0.5 \mathrm{mT}$ and $g=1.9794 \pm 0.0005$, and in the crystal phase $\mathrm{CaO}$, accordingly, $A=1.83 \pm 0.5 \mathrm{mT}$ and $g=1,9735 \pm 0.0005[17]$.

The EPR signals of impurity crystal phases in tooth enamel are illustrated in Fig. 14. The $I_{1}(\mathrm{Mn})$ signal (ions $\mathrm{Mn}^{2+}$ in the phase $\mathrm{CaCO}_{3}$ ) presented on this drawing, can be registered in many samples of tooth enamel. The intensity of the signals $I_{1}(\mathrm{Mn})$ irregularly changes at the heating of samples in the temperature interval 100- 


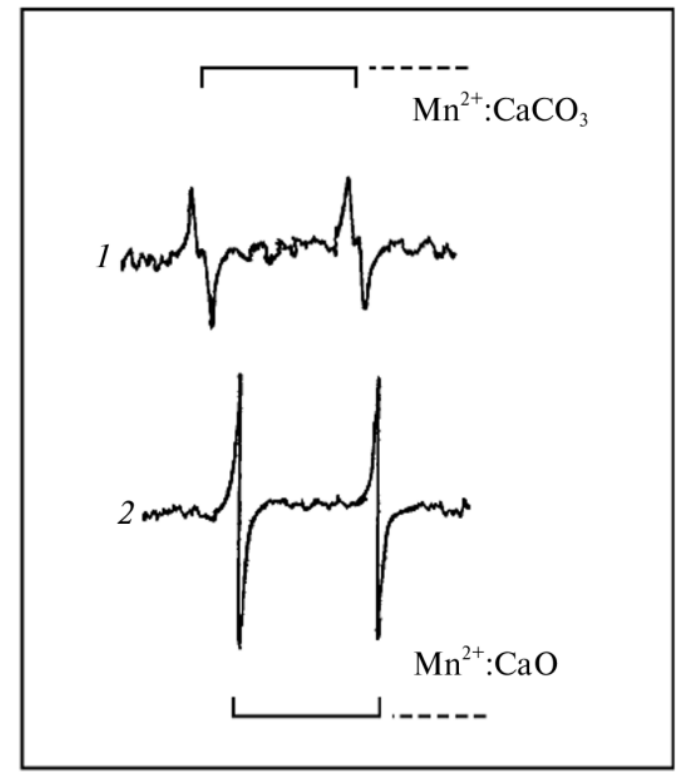

Fig. 14. Fragments of the EPR spectra of human tooth enamel. The top spectrum (1) corresponds to the initial nonheated sample, irradiated by $\mathrm{X}$ rays, and the bottom (2) - to the sample, heated at $T=1000^{\circ} \mathrm{C}$. The spectra 1 and 2 are caused by ions $\mathrm{Mn}^{2+}$, located in phases $\mathrm{CaCO}_{3}$ and $\mathrm{CaO}$, accordingly. The two low-field lines of ions $\mathrm{Mn}^{2 \square}$ are shown in the spectra.

$500^{\circ} \mathrm{C}$. For the enamel samples heated at $600-1000^{\circ} \mathrm{C}$, it is not possible to register the signal $I_{1}(\mathrm{Mn})$. However, in these samples the EPR signals caused ions $\mathrm{Mn}^{2+}$ located in the phase $\mathrm{CaO}$ can be registered (Fig. 14). For tooth enamel affected by caries, the EPR signals caused by ions $\mathrm{Mn}^{2+}$ (localized in impurity phases $\mathrm{CaCO}_{3}$ and $\mathrm{CaO}$ ) is more intensive (by several times) than in the healthy enamel.

Experiments had shown that irradiation of biominerals by $\mathrm{X}$ - and $\gamma$-rays much influence on the intensity of $\mathrm{Mn}^{2+}$ signals of carbonates and oxides, and $\mathrm{Cr}^{3+}$ signals of oxides [17]. The influence of X-rays and $\gamma$-irradiation on charge state of the impurities as a rule is opposite. For example the irradiation of tooth enamel by X-rays leads to increase the signal $I_{1}(\mathrm{Mn})$, but irradiation by $\gamma$-rays, on the contrary, leads to reduction of the signal. The change of charge state of the impurity ions due to the irradiation is caused by a size of the particles [17]. Due to small size, the charge state of impurity ions inside nanodimensional particles is determined by electrical state of the surface of the particles [17], which can be changed by irradiation.

The impurity crystal phases essentially influence on mineralisa- 
tion and demineralisation of bones and teeth and reflect the changes of these tissues due to diseases. The research of impurity crystal phases has a great importance for decision of applied problems related to functioning of bones and regeneration processes in bones with implant materials. The information about impurity crystal phases give new possibilities for study of osteoporosis mechanisms, change the bone characteristics due to aging and due to microgravity conditions.

\section{ANOMALOUS SIGNALS IN SOLID-STATE PARTICLES OF LOW MINERALISED BIOLOGICAL TISSUES}

Mineral particles (or mineral inclusions) are contained not only into highly mineralised tissues. The presence of mineral particles or inclusions is common property of biological tissues [1, 2, 10, 11]. Many biological tissues, including brain tissue, contain small amounts of mineral inclusions. The present chapter is devoted to anomalous signals, which can be registered by EPR spectrometer, into low mineralised biological tissues.

It is well known that the registration of signals by spectrometers of electron paramagnetic resonance is based on changes of characteristics (quality-factor or frequency) of a microwave cavity [35]. These changes appear due to absorption of electromagnetic field energy by samples localized into the cavity. As a rule, the absorption of energy is caused by electron paramagnetic resonance. However, the microwave energy absorption can be irrelevant to EPR phenomenon. Thus, EPR spectrometers can be utilized to study wide range of phenomena connected with absorption or generation of electromagnetic field by investigated samples.

EPR spectrometers are usually used to study the diamagnetic (or paramagnetic) non-metallic materials, which contain different types of paramagnetic centres and broken chemical bonds. As a rule, this class of objects has the 'usual' EPR signals, i.e. signals with the usual form and dynamic characteristics. EPR spectrometers are also utilized for research of ferromagnetic and antiferromagnetic dielectric materials, semiconductors, metals, and superconductors. In these types materials the 'anomalous' signals, whose form and dynamic responses are unusual, can be observed.

The presence of the anomalous signals indicates the existence of special properties of the researched objects and causes heightened interest in them. This interest is related to the search of new physical phenomena, and to search of new materials for solution of applied tasks with the help of non-traditional approaches.

The experimental studies of anomalous signals that are registered in weakly mineralised biological tissues are described in references 
$[10,11]$. Experimental investigations were carried out on mollusc shells and brain tissues. Molluscs of different types (saccinea putris, unio pictorum, lymnaea stagnalis) were used for main measurements. The weakly mineralised organic component of mollusc shells, which coats the outer side of shells, was used for the study. The human and animal (rat) brain tissues were used for the experiments as well.

The typical view of signals registered with the help of EPR spectrometer in tissues of mollusc shells is represented in Fig. 15, $a$. The studied signals have anomalous dynamic characteristics, which are not typical for the usual EPR signals. Additional coherent signals (Fig. 15, $b-\mathrm{e}$ ) appear on the outline of resonance lines when the power of microwave field is greater that the critical value $\left(P>P_{c r}\right)$. The critical value of the microwave field for different situations lies in the interval of $65-85 \mathrm{~mW}$.

The change of EPR spectrum at appearance of coherent signals is illustrated as well in Fig. 16. In windows $a$ and $b$ of the figure represent the EPR lines obtained with the help of computer integration. The spectrums represented in windows $a$ and $b$ in Fig. 16 correspond to microwave powers $P<P_{c r}$ and $P>P_{c r}$, respectively. In the window $c$, the difference of spectrums shown in the windows $a$ and $b$ is represented.

Based on data represented in Fig. 15 and 16, it is possible to conclude the following. If the value of microwave power exceeds the critical value $\left(P>P_{c r}\right)$, on an outline of the signal (this signal caused by resonance absorption of microwaves by the sample) the system of coherent zones can be observed. It is important to emphasize that at $P>P_{c r}$ the value of absorption of microwave power in the area of coherent zones is less than at $P<P_{c r}$. The decrease of absorption of microwave power at $P>P_{c r}$ can be explained with the help of spectrums represented in Fig. 15. The phase of the narrow signal is opposite to the phase of the main EPR signal. Based on this fact, it is possible to conclude that at $P>P_{c r}$ in the area of the narrow signal the absorption of microwave power decreases and the quality-factor of the microwave cavity improves. The increase of quality-factor of the cavity can be caused either by decrease in the amount of resonant paramagnetic centres, which absorb microwave energy, or by generation of electromagnetic waves by the researched sample. In the second case, the coherent zones can be considered as zones generation of electromagnetic waves by biological tissue (Fig. $16)$.

The signal represented in Fig. 15, $a$ is anisotropic. At rotation of a sample the resonance field the signals substantially varies. The angular dependences of the signals have four extremes in the angle interval $0-180^{\circ}$. Thus, the model of usual weakly bounded para- 
magnetic centres with spin $S=1 / 2$ is not sufficient for describing of these angular dependences.

Several types of resonance signals with different widths $\Delta B$ were discovered in brain tissues [11]. We divide these signals in two groups: the narrow signals with $\Delta B \approx(5-8) \mathrm{mT}$ and the broad signals with $\Delta B \approx(12-150) \mathrm{mT}$. The dynamic characteristics of narrow signals in brain and mollusc shells are similar. For brain tissue at high level of microwave power, parabolic zones, caused by manifestation of quantum oscillations, appeared on the outline of the narrow resonance signals. Based on the experiments, the conclusion is made that the properties of magnetic areas that produce narrow signals in brain tissues and mollusc shells are similar. Note that the splitting of narrow signals by microwave field in experiments $[10$, 11] is similar to splitting of signals that was described in Refs. [36, 37].

The estimation of the concentration of magnetic centres in local

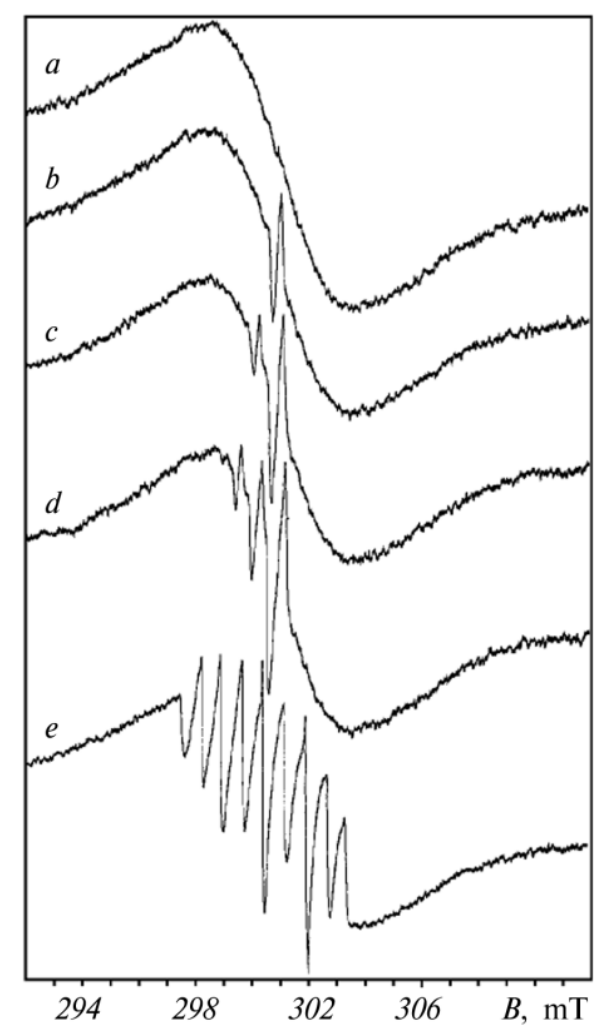

Fig. 15. Resonance lines in tissues of mollusc shells. The attenuation of microwave power for spectrums $a-e$ is equal to $1.80,1.70,1.65,1.60$, and $0.80 \mathrm{~dB}$, respectively. 
areas of brain tissues was described in Ref. [11]. The local concentration of centres appeared to be greater than $10^{22}$ spin/gramme. Such a high concentration is not typical for paramagnetic ions in biological tissues. Accordingly, it is possible to make the conclusion that the resonance signals in brain tissues are caused by mineral inclusions in the tissue.

The comparison of signals in different samples of brain tissues was performed in reference [11]. It was established that the narrow signals have much lower peak intensity that the broad signals. It was supposed that intensity of the signals is proportional to volume of area that produces these signals. Therefore, the size of areas that produce the broad signals is much greater than the size of areas that produce the narrow signals.

The splitting of the resonance signals by strong microwave field [10] can be described by the model of exchange-bounded centres. Let us assume that the magnetic dipoles $\mu_{1}$ and $\mu_{2}$ have close, but unequal resonance fields. Due to the exchange interaction, the resonance fields of these centres will vary. At substantial exchange interaction, the two paramagnetic centres with magnetic dipoles $\mu_{1}$ and $\mu_{2}$ will form a united system. This united system will have single resonance line with an average resonance field. The strong mi-

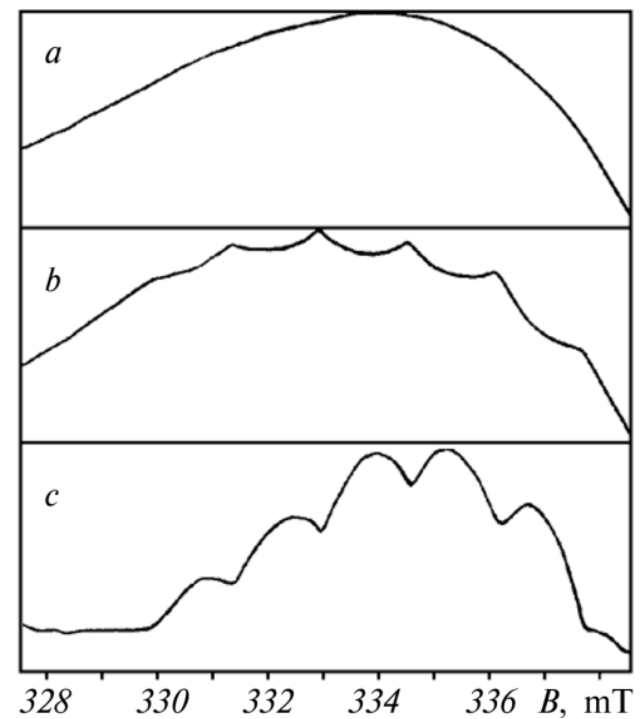

Fig. 16. Absorption lines of microwave power obtained with the help of computer integration of experimental spectra (windows $a$ and $b$ ), and the difference of the absorption lines (window $c$ ). The spectrum in window $c$ can be considered as generation zones of microwave field by studied sample. 
crowave field, apparently, influences on exchange-related narrowing of the resonance line due to influence on the movement of electrons between different ions. It is possible to assume that the strong microwave field leads to localization of magnetic moments and, accordingly, to splitting of the exchange-narrowed resonance lines.

As well known, different types of non-linear phenomena take place for ferromagnetic and antiferromagnetic resonance [38]. The non-linear phenomena are caused by strong alternating resonance field and have the threshold character. It is possible to assume that that above-mentioned splitting of resonance signals in mollusc shells and brain can be explained by means of the non-linear effects in ferromagnetic and antiferromagnetic resonances.

As known [2], both physiological (normal) and pathological biomineralisation occurs in many biological tissues. The physiological mineralisation (for example, formation of bone and tooth enamel) takes place if an organic matrix is able to control the deposition of mineral particles [2-4]. The pathological mineralisation (formation of stones in various biological tissues) arises when the organic matrix by any reasons (for example, change in composition of macromolecules, appearance of free radicals, etc.) loses the ability to control the mineralisation process $[2,12]$. It is known that if the size of mineral particles exceeds the critical value, then the organic matrix cannot control the growth of the particles. In this case, the physiological mineralisation transforms to pathological mineralisation. As a result, uncontrolled grows takes place and pathological inclusions are formed in the biological tissue.

Based on experimental results, it is possible to make the conclusion that the brain tissues have both physiological and pathological biomineralisation [11]. The mineral particles that have narrow resonance lines are the product of physiological mineralisation, and the mineral particles that have broad resonance lines are the product of pathological mineralisation. Different organic matrices can stimulate formation of different mineral substances. The brain tissues promote deposition of oxides and hydroxides of iron. We believe that the mineral areas play an important role in processes related to functioning of the brain. We think that mineral particles formed due to physiological biomineralisation play an important role in storage and processing of information, and pathological mineral particles can be a cause of various diseases of the brain.

The formation of nanoscale mineral particles that produce the narrow lines is a physiological (normal) process of brain tissues. We think that in the brain tissues, in addition to well-known mechanisms of information storage [39], there are also other mechanisms based on processes in magnetic inclusions that are associated with neurons of the brain. 
The results described in this chapter open new possibilities for solution of applied problems. Among such applied problems, it is possible to note the problems that relate to creation of quantum (biological) computers and to study the mechanisms of brain diseases. It is important to note that the study of mineral particles in brain tissues using physical methods is the task of solid-state physics. Thus, the processes in brain tissues can be described using the strict physical methods.

\section{CONCLUSION}

The results related to structure and properties of nanoscale solidstate particles into biological tissues are described in the paper. The analysis of new results and results published recently is performed. The new approaches for study of the high-mineralised biological tissues and mineral inclusions into weakly mineralised tissues are discussed in the paper as well.

As shown, hierarchy of internal construction of tooth enamel and bones can be studied successfully by electron paramagnetic resonance and other radiospectroscopic methods. Study the hierarchy of internal construction of biominerals play important role for describing different type processes into mineralised biological tissues. We had shown that tooth enamel and bones have to be considered as the special mineral-organic nanoassociated (MONA) systems, which have special structure and properties. Organic layers, barrier layers and nanocrystals, which have non-equilibrium electrical charges, can be considered as structural units in these systems. The electrical charges of the structural units influence essentially on processes into biominerals. The charges can be varied due to different internal and external factors. For example, the electrical charge can be changed due to the microgravity conditions during space flight. Nanodimensional piezoelectric effect is an important property of the biominerals. Due to this effect and hierarchy of internal construction, the biominerals are in a state of electrically polarized and mechanically stressed biotexture.

Development of new approaches for study interaction mechanisms of mineral and organic matter into mineralised biological tissues is actual problem. The information about the mechanism is important for many applications. The information plays important role for successful treatment of bones by resorbed implants manufactured on the base of hydroxylapatite. Assimilation processes of the implanted material by live bone tissue are discussed in the paper. The assimilation processes are considered at level of free radicals and nanoscale subsystems. It is shown, that the information about interaction mechanisms of an organic and mineral matter and about 
assimilation processes of implants by bone tissue can be obtained with the help of native free radicals $R_{n}$ and by carbonate radicals $\mathrm{CO}_{2}^{-}$. EPR study of these radicals gives unique information about interaction mechanisms of organic and mineral matter into bone tissue. The dynamic of the $R_{n}$ and $\mathrm{CO}_{2}^{-}$radicals reflects the assimilation processes of implant material by bone. The information about the assimilation processes promote for creation of physical models for bone tissue and serve for improving of resorbed implant materials, which are used for treatment of bone diseases. The EPR study promotes for understanding the processes, which lead to transformation of lifeless implant material into the living biological tissue.

Anisotropy of bones and tooth enamel are determined by genetic factors and caused by the anisotropy of organic matrix of the biominerals. Anisotropy of tooth enamel and bones are changed due to aging of biological object and due to diseases of the biological tissues. Information about anisotropy of bones and tooth enamel serve for development of countermeasures, which give possibilities to prevent the diseases. Peculiarities of the internal construction of tooth enamel and bones, which are the cause of the anisotropy, are described in the paper. The EPR signal anisotropy reflect the anisotropy of organic matrix the biominerals because orientation of nanocrystals is caused by organic matrix. The bioepitaxy phenomenon plays important role in anisotropy of biominerals. Disease of teeth and bones produces changes in properties of the mineral and organic components of the biomineral that lead to change of EPR spectra. We have grounded the study of enamel and bone properties by texture coefficients, which reflect the anisotropy of EPR signals of the biominerals. The texture coefficients give possibilities to estimate the changes of bones and teeth structure due to their diseases.

Impurity crystal phases play an important role in functioning of high-mineralised biological tissues. The quantity and type of impurity crystal phases into bones are changed due to aging and bone diseases. The impurity phases influence on regeneration processes of bones caused by using of resorbed implant materials. Disease of teeth by caries leads to changes of phase composition of the mineral component of enamel. The information about impurity crystal phases in the bone tissue is of great importance for study of osteoporosis mechanisms and change of bone characteristics with aging. Results given in this paper had shown that the EPR method has unique possibilities for study of impurity crystal phases in biominerals and their synthetic analogues. These possibilities are based on high-sensitivity of EPR method and on sensitivity of EPR signal parameters to the symmetry of crystal lattices where the paramagnetic ions are localized. Small changes of crystal structure around 
the paramagnetic ion result in essential changes of the EPR spectra. The quantities of impurity crystal phases, which can be registered by the EPR method, make up approximately about $0.1 \%$ of total weight of examined samples. It is known that the restrictions of the X-ray phase analyse method are due to the size of particles of examined substance (particles should have sizes more than the areas of coherent scattering). The EPR method is less critical to the size of crystal particles and to defectiveness (or amorphousness) of the crystal lattices of the particles. The size of particles in limits of one-two elementary cells is sufficient for diagnostics of the crystal lattice type by EPR method. We believe that impurity carbonate phases of bones perform a role of the depot where microelements are located.

Dynamics of charge state transformation (during heating and irradiation) of manganese and chromium ions localized into impurity crystal phases is described in the paper. The new phenomenon related to charge state of impurity ions is discussed. It has been determined that the charge state of impurity ions into nanoscale particles much depends on irradiation of the samples. We believe that electrical state of surface influence on electrical state of the paramagnetic ions and that the surface electrical state can be changed by irradiation of samples.

Anomalous resonance signals in weakly mineralised tissues attract special interest because the signals can be registered into brain tissue. The anomalous resonance signals were registered by means of EPR spectrometer. However, the anomalous signals do not relate to EPR phenomenon and could not be caused by the usual weakly bounded paramagnetic centres. The anomalous signals possess the unique dynamic properties. At high level of microwave power, parabolic zones, caused by manifestation of quantum oscillations, appeared on the outline of the anomalous resonance signals. Two types of anomalous signals (narrow and broad) can be registered in brain tissues. We think that exchange bounded paramagnetic centres, which are localized in nanoscale magnetic particles, cause narrow resonance signals, and broad signals are caused by antiferromagnetic or ferromagnetic particles, which have dimensions in micrometer range. We believe that biomineralisation process takes place within brain tissue. Because of the biomineralisation, both physiological (normal) and pathological mineral solid-state particles are formed in brain tissue. We believe that the narrow and broad resonance signals in brain tissues are produced by physiological (normal) and pathological mineral particles, accordingly. We think that physiological magnetic particles play an important role in operation of the brain, and pathological particles can be a cause of brain diseases. 
The results described in this paper open new possibilities for solving fundamental problems related to functioning and diseases of the mineralised biological tissues. The described new approaches for study of nanoscale mineral particles localized into biological tissues, open the new possibilities for solution of applied problems by nontraditional methods. It is important to note that mineral component of high-mineralised tissues and mineral inclusions into low mineralised tissues have the structure of solid-state particles. It opens possibilities for using of the strict physical approaches for describing of the processes into biological tissues. Besides, the information about properties of nanoscale solid-state particles localized into biological tissues opens possibilities for creation of technical systems and equipments, which would use the principles of biological tissue functioning.

\section{REFERENCES}

1. A. P. Shpak, A. B. Brik, and V. L. Karbovskij, Tezisy Dokladov Mezhdunarodnoj Konferentsii 'Noveishie Tekhnologii v Poroshkovoj Metallurgii i Keramike’ (Kyyiv: 2003), p. 286 (in Russian).

2. A. A. Korago, Vvedenie v Biomineralogiyu (Spb.: Nedra: 1992) (in Russian).

3. F. C. M. Driessens and R. M. H. Verbeeck, Biominerals (Boca Raton: CRC Press: 1990).

4. H. A. Lowenstam and S. Weiner, On Biomineralization (New York: Oxford Univ. Press: 1989).

5. A. P. Shpak, V. L. Karbovskij, and V. V. Trachevskij, Apatity (Kyyiv: Akademperiodyka: 2002) (in Russian).

6. T. Kanazawa, Neorganicheskie Fosfatnyye Soyedineniya (Kyyiv: Naukova Dumka: 1998) (in Russian).

7. N. P. Jushkin, V. I. Pavlishin, and A. M. Askhabov, Mineralogicheskij Zhurnal, 25, No. 4: 7 (2003) (in Russian).

8. L. G. Rosenfeld, A. B. Brik, G. H. Kenner, O. N. Atamanenko et al., Ortopediya, Travmatologiya i Protezirovanie, No. 1: 9 (2002) (in Russian).

9. L. G. Rozenfel'd, O. B. Brik, and O. N. Atamanenko, Zhurnal AMN Ukrainy, 5, No. 2: 220 (1999) (in Russian).

10. A. B. Brik, Mineralogical Journal, 24, No. 5/6: 29 (2002).

11. A. B. Brik, Mineralogical Journal, 25, No. 2/3: 11 (2003).

12. A. B. Brik and V. B. Brik, Mineralogical Journal, 20, No. 5: 46 (1998).

13. E. V. Borovskij and V. K. Leont'ev, Biologiya Polosti Rta (Moscow: Medicina: 1991) (in Russian).

14. M. J. Glimcher, Clinical Ortopaedics and Related Research, No. 61: 16 (1968).

15. D. V. Provenza and W. Ed. Seibel, Oral Histology (Philadelphia: Lea and Febiger: 1986).

16. A. B. Brik, E. H. Haskell, V. B. Brik, O. N. Atamanenko, and O. I. Scherbina, Appl. Radiat. Isot., 52: 1077 (2000).

17. A. Brik, G. Kenner, V. Brik, E. Rice et al., Mineralogical Journal, 23, No. 
1: 23 (2001).

18. G. P. Stupakov and A. I. Volozhin, Kostnaya Sistema i Nevesomost' (Moscow: Nauka: 1989), vol. 63 (in Russian).

19. A. M. Belous and E. Ya. Pankov, Mekhanizmy Regeneratsii Kostnoj Tkani: Sbornik Statej (Moscow: Medicina: 1972) (in Russian).

20. W. F. Neuman and M. W. Neuman, The Chemical Dynamics of Bone Mineral (Chicago: The University of Chicago Press: 1958).

21. R. O. Becker and F. M. Brown, Nature, 206, No. 4991: 1325 (1965).

22. C. A. L. Bassett, Calcif. Tiss. Res., 1: 252 (1968).

23. W. S. Williams and L. Breger, J. Biomechanics, 8: 407 (1975).

24. V. I. Loshchilov, M. V. Volkov, and S. I. Shchukin, Dokl. AN SSSR. Ser. Biofizika, 274, No. 5: 1221 (1984) (in Russian).

25. E. T. Kulin, Bioehlektretnyj Ehffekt (Minsk: Nauka i Tekhnika: 1980) (in Russian).

26. A. B. Brik, E. H. Haskel, O. I. Scherbina et al., Mineralogical Journal, 20, No. 4: 26 (1998).

27. F. Callens, P. Moens, and R. Verbeeck, Calcified Tissue International (1995), p. 543 .

28. A. B. Brik, O. I. Scherbina, E. H. Haskell et al., Mineralogical Journal, 19, No. 4,3 (1997).

29. S. S. Ishchenko, I. P. Vorona, S. M. Okulov, and N. P. Baran, Applied Radiation and Isotopes, 56: 815 (2002).

30. I. P. Vorona, M. P. Baran, and S. S. Ishchenko, Ukr. Fiz. Zhurnal, 47, No. 7: 659 (2002) (in Russian).

31. A. Brik, V. Baraboy, O. Atamanenko et al., Applied Radiation and Isotopes, 52, No. 5: 1305 (2000).

32. A. B. Brik, O. N. Atamanenko, I. G. Litovka, and O. I. Scherbina, Abstracts of 22nd Annual International Gravitational Physiology Meeting (Budapest, 2001 ), p. 61.

33. L. G. Gelinskaja and M. Ya. Shcherbakova, Fizika Apatita (Novosibirsk: Nauka: 1975), p. 7 (in Russian).

34. A. Abragam and B. Bleaney, Electron Paramagnetic Resonance of Transition Ions (Oxford: Clarendon Press: 1970).

35. Ch. P. Pool, Electron Spin Resonance in Comprehensive Treatise on Experimental Techniques (New York-London-Sidney: Interscience Publishers-a Division of John Wiley and Sons: 1967).

36. Z. Srebro, W. Froncize, T. Sarna, and S. Lukiewicz, Proc. of the First European Biophysics Congress (1971), vol. 2, p. 575.

37. P. Milvy, S. Kakari, J. B. Campbell, and H. B. Demopoulos, Annals of New York Academy of Science, 222: 1102 (1976).

38. Ferromagnitnyj Rezonans (Ed. S. V. Vonsovskij) (Moscow: GIFML: 1961) (in Russian).

39. F. E. Bloom, A. Lazerson, and L. Hofstadter, Brain, Mind, and Behavior (New York: W. H. Freeman and Company: 1985). 